\title{
Effect of slaughter age and breed on the carcass traits and meat quality of beef steers finished on natural pastures in the arid subtropics of South Africa
}

\author{
I. du Plessis ${ }^{1,2 \#}$ and L.C. Hoffman ${ }^{2}$ \\ ${ }^{1}$ Limpopo Province Department of Agriculture, Mara Research Station, Private Bag X2467, Louis Trichardt 0920, \\ South Africa \\ ${ }^{2}$ Department of Animal Sciences, University of Stellenbosch, Private Bag X1, Matieland 7602, South Africa
}

\begin{abstract}
Simmentaler cross (SX), Bonsmara cross (BX) and Nguni (NG) steers were raised on natural sweet veld pastures and slaughtered at 18 or 30 months of age. Slaughtering occurred at the end of the wet summer season. Live weight and carcass traits were significantly influenced by breed and slaughter age. The amount as well as percentage kidney and omental fat differed significantly between the respective slaughtering ages, but only between breeds at 30 months of age. Breed and slaughter age affected back-fat thickness. All fat parameters were lower at 18 months than at 30 months of age. Breed did not have a large influence on meat quality attributes, but age did. Drip loss was similar for the breeds and slaughter age groups. The meat was darker and more red at 30 months than at 18 months of age. The $\mathrm{pH}_{24}$ of the longissimus muscle was 5.51 and 5.67 at 18 and 30 months of age, respectively. No breed differences were detected for sensory panel attributes or Warner-Bratzler shear force values. Sensory panel tenderness and Warner-Bratzler shear force values indicated tougher meat from 30-month old steers than from 18-month old steers. Differences in meat quality were probably due to the combined effects of fatness, $\mathrm{pH}$ and collagen characteristics. It is concluded that in sweet veld areas steers from small- to medium-framed breeds can be raised successfully and slaughtered at 30 months of age without supplementation of natural pastures. Slaughtering steers at younger ages may require supplementary feeding or feedlot finishing.
\end{abstract}

Keywords: Beef, carcass traits, meat quality, natural pasture, arid

\#Corresponding author. E-mail: duplessisizak@yahoo.com

\section{Introduction}

Beef is produced either intensively in feedlots, or semi-intensively or extensively from pastures. The dietary effect on carcass and meat quality of cattle has been researched intensively. Varying dietary energy levels (Prior et al., 1977; Loveday \& Dikeman, 1980; Crouse et al., 1985a) as well as grain vs. forage based diets (Bowling et al., 1977; Young \& Kauffman, 1978; Schroeder et al., 1980; Crouse et al., 1984; Fortin et al., 1985; Newsome et al., 1985; Bidner et al., 1986) or pasture vs. feedlot finishing (Schaake et al., 1993; Bennett et al., 1995; Camfield et al., 1999) and breed types/frame size (Koch et al., 1976; Cianzio et al., 1982; Tatum et al., 1986a; Tatum et al., 1990; Dolezal et al., 1993; Camfield 1997; Short et al., 1999) were the focus of various research studies abroad. In general, carcasses from feedlot-fed cattle are heavier and contain more fat than carcasses from forage-fed cattle. Beef from forage fed cattle is also darker and less tender than meat from feedlot-fed cattle. Most of these studies were conducted in the USA where consumers prefer heavier carcasses exhibiting a substantial degree of marbling. In South Africa consumers prefer lean meat with little visible fat. Here carcasses are produced to suit consumer preferences and are seldom trimmed of excess fat.

In South Africa research concerning the utilization of forage revolved around nutritional, reproductive and growth responses following supplementation on sour veld pastures (Erasmus \& Barnard, 1985; Gertenbach \& Van H. Henning, 1995a), and enhancing the nutritional value of planted pastures (Le Roux et al., 1999; Taute et al., 2002) as well as crop residues (Cloete \& Kritzinger, 1985; Brand et al., 1989; Snyman \& Joubert, 2002). Most carcass and meat quality related research revolved around feedlots (Meaker \& Barnard, 1988; Casey et al., 1990; Swanepoel et al., 1990; Gertenbach \& Van H. Henning, 1995b; Strydom et al., 2000; Strydom et al., 2001). At the Mara Research Station research on natural pastures (sweet veld) focused on cow production and efficiency (Venter, 1977; Van Zyl, 1990; Lademann, 1992; Meaker, 1993). 
The possibility exists that beef produced from natural sweet pastures can, apart from meeting consumer expectations, also be classified as organically produced. This enables the producer to add value to his product by targeting this niche market. Marketing at 30 months of age will result in higher returns per animal as a much heavier carcass can be sold than at 18 months of age. The weight gained during this period will more than compensate for the lower price/kg that results from marketing older carcasses, especially if there is no substantial difference in the prices for the different carcass classes. However, no information is available on the effects of genotype and age of cattle kept under sweet veld grazing conditions on carcass characteristics.

The objectives of this study were to evaluate breed types suitable for finishing off on natural, sweet pastures as well as the influence of age at slaughter on their carcass and meat quality.

\section{Materials and methods}

The study was conducted from 1999 to 2003 on ca. 4387 ha on the eastern side of the Mara Research Station (23 ${ }^{\circ} 05^{\prime} \mathrm{S}$ and $29^{\circ}$ 25' E; 961 m.a.s.l). The Mara Research Station is situated in the Arid Sweet Bushveld (Acocks, 1988). The vegetation in the study area included the woody species Acacia tortilis, Commiphora pyracanthoides, Boscia albitrunca and Grewia spp. and the grass species Eragrostis rigidior, Panicum maximum, Urochloa mosambicensis and Digitaria eriantha (Dekker et al., 2001). The long-term mean annual rainfall at the Mara Weather Station is $452 \mathrm{~mm}$ of which $c a$. $80 \%$ falls from November to March. The mean daily maximum temperature ranges from $22.6{ }^{\circ} \mathrm{C}$ in June to $30.4{ }^{\circ} \mathrm{C}$ in January. During the study period, the mean annual rainfall (measured from July to June) was $410 \mathrm{~mm}$, ranging from $232 \mathrm{~mm}$ to $846 \mathrm{~mm}$ per annum.

In this investigation the productivity of three different breeds/frame sizes on sweet veld was evaluated. Simmentaler cross (SX), Bonsmara cross (BX) and Nguni (NG) steers representing large-, medium- and small-framed types, respectively, were used in this study. Animal origin and general animal husbandry practices were described in more detail by Du Plessis \& Hoffman (2004).

Steers born during a specific calving season were randomly divided into three groups and slaughtered at two different ages, namely at 18 or 30 months of age. Steers born from October 1999 to December 2001 were slaughtered either in May 2002 or May 2003. Slaughtering coincided with the end of the wet summer season. The live weights (LW) of the steers were recorded at 28 day intervals after withholding food and water for at least $12 \mathrm{~h}$. Live weights at 18 and 30 months of age (548 and 912 days of age respectively) were either interpolated or extrapolated from the 28 day weight records.

On the day of slaughter steers were transported for $35 \mathrm{~km}$ to the abattoir. Steers were slaughtered using standard South African techniques and conditions. Care was taken to ensure that all ante mortem factors were standardized as far as possible.

Carcasses were quartered $48 \mathrm{~h}$ post-mortem, whereafter all carcass measurements were recorded and sampling was conducted. Cold carcass weight (CCW) was also corrected for age. Dressing percentage (DP) was calculated as the proportion of the CCW of the LW. Carcass length was measured from the centre of the first rib to the centre of the pubic symphysis and used to calculate carcass compactness $(\mathrm{kg} / \mathrm{cm}$; Swanepoel et al., 1990). Back-fat thickness (BFT) was measured at the $12^{\text {th }}$ rib, ca. $5 \mathrm{~cm}$ from the dorsal midline. All kidney (KF) and omental fat (OF) were removed, weighed and expressed as a percentage of carcass weight.

The prime rib cuts $\left(9^{\text {th }}, 10^{\text {th }}\right.$ and $11^{\text {th }}$ ribs) were removed from both sides of the carcasses. The $M$. longissimus dorsi (longissimus muscle) from the left rib cut was immediately dissected, labelled and kept at $4{ }^{\circ} \mathrm{C}$ until drip losses were determined later on the same day. Drip and cooking losses were determined according to the methods set out by Honikel (1998). Cooking losses (cooked for 1 hour at $80{ }^{\circ} \mathrm{C}$ ) were determined 72 hours post-mortem. Cooked samples were cooled in running water at room temperature $\left(\sim 25^{\circ} \mathrm{C}\right)$ prior to determining the final weight.

To determine Warner-Bratzler shear force (WBS) values, five $12.7 \mathrm{~mm}$ diameter cores were cut perpendicular to the longitudinal axis of the muscle fibres at a crosshead speed of $299 \mathrm{~mm} / \mathrm{min}$ (Voisey, 1976) from the same samples used to determine cooking loss. The mean for the WBS-values of the five cores was calculated.

Colour measurements (average of three random measurements) were taken from the surface of freshly cut steaks after a 20 minute blooming period (Stevenson et al., 1989) using a Color-guide $45^{\circ} / 0^{\circ}$ colorimeter 
(BYK-Gardener, USA) with scales for lightness ( $\mathrm{L}^{*} ; 0=$ black, $100=$ white), redness $\left(\mathrm{a}^{*} ;+=\right.$ red, $-=$ green) and yellowness ( $\mathrm{b}^{*} ;++=$ yellow, - = blue).

After trimming, the right side longissimus muscle was labelled, vacuum packed, frozen and stored at $-18{ }^{\circ} \mathrm{C}$ until the sensory evaluations were made.

Sensory evaluations were conducted on the longissimus muscle of the prime rib cut $\left(9^{\text {th }}, 10^{\text {th }}\right.$ and $11^{\text {th }}$ ribs) from the right side of the carcasses from steers slaughtered at 18 and 30 months of age in May 2003. As different age groups were slaughtered at intervals of 12 months, comparisons between groups slaughtered in different years could not be made. Before the sensory evaluation, the longissimus muscle samples were thawed for $24 \mathrm{~h}$ at a temperature of 2-4 ${ }^{\circ} \mathrm{C}$. Meat samples were cut to a uniform size and placed on foil covered metal racks. Each metal rack was placed in a coded cooking bag and a probe inserted into the centre of the meat. The samples were roasted at $160{ }^{\circ} \mathrm{C}$ (Viljoen et al., 2001) to an internal temperature of $68{ }^{\circ} \mathrm{C}$ (American Meat Science Association, 1978). The meat was allowed to rest for 5 min, during which time an endpoint temperature of $72{ }^{\circ} \mathrm{C}$ was reached. Cubed samples $(1.5 \mathrm{~cm}$ x $1.5 \mathrm{~cm})$ were taken from the middle of each longissimus muscle sample and individually wrapped in aluminium foil. The samples were placed in preheated glass ramekins marked with random three-digit codes and placed in a preheated oven at $100{ }^{\circ} \mathrm{C}$ and evaluated within 10 min.

Descriptive sensory analyses were performed on the meat samples. Five panelists were selected and trained in accordance with the guidelines for the sensory evaluation of meat (American Meat Science Association, 1978). The meat samples were evaluated for the following sensory attributes: beef aroma intensity, initial impression of juiciness, sustained juiciness, tenderness, residue and overall beef flavour, by means of an eight-point structured scale. The meat was evaluated in 12 sessions, controlled for age per session. The panelists were seated in individual booths in a temperature and light-controlled room, receiving a set of three samples served in a complete randomized order.

Carcass and meat trait results were analyzed statistically with a univariate ANOVA using the GLM procedure. Breed and age at slaughter were included as the main effects. Least significant differences were determined between means. The experimental design of the sensory evaluation consisted of a randomized incomplete block design. The treatment design was a $3 \times 2$ factorial design with three breeds and two slaughter age groups as the main factors. Where appropriate, data were also pooled to test for the main effects of breed and slaughter age. Prior to analyses of variance, the sensory scores were transformed to ranks. Tukey's LSD was calculated at a 5\% significance level to compare treatment means (SAS, 1990).

\section{Results}

Breed and slaughter age had an effect $(\mathrm{P}<0.05)$ on live and carcass weight and carcass compactness of the beef steers (Table 1). Simmentaler crosses presented the highest $(\mathrm{P}<0.05)$ values for the above parameters, with the lowest $(\mathrm{P}<0.05)$ derived from NG. These parameters were also influenced $(\mathrm{P}<0.05)$ by slaughter age. However, neither breed nor slaughter age had any influence $(\mathrm{P}<0.05)$ on DP.

Both amount and proportion of KF presented an interaction $(\mathrm{P}<0.05)$ between breed and slaughter age. At 30 months of age both the amount and percentage of KF were higher $(\mathrm{P}<0.05)$ in NG $(2709.3$ $\pm 256.65 \mathrm{~g}$ and $1.3 \pm 0.0133 \%$, respectively) than in either SX $(1706.9 \pm 224.21 \mathrm{~g}$ and $0.71 \pm 0.0876 \%$, respectively) or $\mathrm{BX}(2101.9 \pm 193.81 \mathrm{~g}$ and $0.95 \pm 0.0678 \%$, respectively), with no differences $(\mathrm{P}>0.05)$ between breeds at 18 months of age. In BX and NG, KF was lower at 18 months of age (1255.1 \pm 72.05 and $1082.6 \pm 73.58 \mathrm{~g}$, respectively) than at 30 months of age, whereas percentage KF was higher at 30 months of age than 18 months of age only in NG (0.81 $\pm 0.0504 \%)$.

Amount of OF was highest $(\mathrm{P}<0.05)$ in NG $(2896.1 \pm 117.58 \mathrm{~g})$ at 30 months of age, whereas SX $(1614.7 \pm 255.33 \mathrm{~g})$ and $\mathrm{BX}(2343.2 \pm 166.17 \mathrm{~g})$ also differed $(\mathrm{P}<0.05)$ from each other. In both BX and NG, OF was lower at 18 months of age (1520.5 and $1666.9 \mathrm{~g}$, respectively) than at 30 months of age. However, OF as a proportion, was only influenced by breed (Table 1). Similar to BFT, the lowest $(\mathrm{P}<0.05)$ values for percentage OF were found in SX, and the highest $(\mathrm{P}<0.05)$ in NG (Table 1). Backfat thickness was also lower $(\mathrm{P}<0.05)$ at 18 months than at 30 months of age.

The $\mathrm{pH}_{24}$ (Table 1$)$ did not differ $(\mathrm{P}>0.05)$ among the breed types, but was lower $(\mathrm{P}<0.05)$ at 18 months of age than at 30 months of age. No significant differences among breed types or slaughter age were observed for drip and cooking losses. Whereas breed did not influence $(\mathrm{P}>0.05)$ any of the colour 
measurements, both $\mathrm{L}^{*}$ were lower $(\mathrm{P}<0.05)$, and $\mathrm{a}^{*}$ values higher $(\mathrm{P}<0.05)$, at 30 months of age, indicating meat with a darker and more red colour.

Table 1 Carcass, fat and meat characteristics (means \pm s.e.) of beef steers finished on natural pastures in the arid subtropics of South Africa as influenced by breed and slaughter age

\begin{tabular}{|c|c|c|c|c|c|}
\hline \multirow{2}{*}{ Parameter } & \multicolumn{3}{|c|}{ Breed $^{\#}$} & \multicolumn{2}{|c|}{ Slaughter age (Months) } \\
\hline & SX & $\mathrm{BX}$ & NG & 18 & 30 \\
\hline Live weight (kg) & $446.1^{\mathrm{a}} \pm 22.50$ & $378.8^{\mathrm{b}} \pm 17.87$ & $346.7^{\mathrm{C}} \pm 11.53$ & $309.2^{\mathrm{b}} \pm 7.80$ & $441.5^{\mathrm{a}} \pm 9.81$ \\
\hline Carcass weight (kg) & $216.8^{\mathrm{a}} \pm 12.11$ & $182.3^{\mathrm{b}} \pm 8.65$ & $166.2^{\mathrm{C}} \pm 5.99$ & $148.9^{\mathrm{b}} \pm 4.42$ & $212.5^{\mathrm{a}} \pm 5.18$ \\
\hline Dressing \% & $48.5 \pm 0.75$ & $48.5 \pm 1.53$ & $47.9 \pm 0.40$ & $48.3 \pm 1.09$ & $48.1 \pm 0.42$ \\
\hline Carcass compactness $(\mathrm{kg} / \mathrm{cm})$ & $0.85^{\mathrm{a}} \pm 0.03$ & $0.73^{\mathrm{b}} \pm 0.02$ & $0.71^{\mathrm{C}} \pm 0.02$ & $0.65^{\mathrm{b}} \pm 0.01$ & $0.83^{\mathrm{a}} \pm 0.01$ \\
\hline \multicolumn{6}{|l|}{ Fat characteristics } \\
\hline Kidney fat (g) & $1399.4 \pm 170.1$ & $1613.4 \pm 122.6$ & $1919.2 \pm 194.0$ & $1137.2 \pm 48.1$ & $2328.8 \pm 160.1$ \\
\hline Kidney fat (\%)* & $0.64 \pm 0.0589$ & $0.89 \pm 0.0446$ & $1.10 \pm 0.0863$ & $0.78 \pm 0.0368$ & $1.12 \pm 0.0839$ \\
\hline Omental fat (g) & $1520.4 \pm 151.5$ & $1868.5 \pm 122.8$ & $2299.1 \pm 126.8$ & $1569.9 \pm 59.2$ & $2478.0 \pm 121.4$ \\
\hline Omental fat (\%)* & $0.71^{\mathrm{C}} \pm 0.0570$ & $1.03^{\mathrm{b}} \pm 0.0494$ & $1.37^{\mathrm{a}} \pm 0.0482$ & $1.09 \pm 0.0521$ & $1.19 \pm 0.0651$ \\
\hline Back fat thickness (mm) & $1.06^{\mathrm{a}} \pm 0.18$ & $2.39^{\mathrm{b}} \pm 0.39$ & $4.19^{\mathrm{a}} \pm 0.46$ & $2.11^{\mathrm{b}} \pm 0.25$ & $3.99^{\mathrm{a}} \pm 0.50$ \\
\hline \multicolumn{6}{|l|}{ Meat characteristics } \\
\hline $\mathrm{pH}_{24}$ & $5.62 \pm 0.07$ & $5.60 \pm 0.03$ & $5.50 \pm 0.05$ & $5.48^{\mathrm{b}} \pm 0.05$ & $5.64^{\mathrm{a}} \pm 0.02$ \\
\hline Drip loss (\%) & $1.46 \pm 0.18$ & $1.57 \pm 0.09$ & $1.55 \pm 0.12$ & $1.64 \pm 0.09$ & $1.44 \pm 0.10$ \\
\hline Cooking loss (\%) & $34.6 \pm 0.48$ & $33.3 \pm 0.51$ & $32.9 \pm 0.56$ & $34.2 \pm 0.23$ & $32.4 \pm 0.60$ \\
\hline \multicolumn{6}{|l|}{ Colour } \\
\hline $\mathrm{L}^{*}$ & $34.84 \pm 0.60$ & $35.69 \pm 0.50$ & $35.21 \pm 0.29$ & $36.59^{\mathrm{a}} \pm 0.30$ & $34.03^{\mathrm{b}} \pm 0.25$ \\
\hline$a^{*}$ & $13.04 \pm 0.40$ & $13.14 \pm 1.48$ & $13.97 \pm 0.29$ & $12.63^{\mathrm{b}} \pm 0.20$ & $14.44^{\mathrm{a}} \pm 0.24$ \\
\hline $\mathrm{b}^{*}$ & $9.33 \pm 0.40$ & $9.47 \pm 0.26$ & $9.89 \pm 0.27$ & $9.65 \pm 0.20$ & $9.66 \pm 0.28$ \\
\hline
\end{tabular}

a,b,c Column means within breed and slaughter age with different superscripts differ $(\mathrm{P}<0.05)$

${ }^{\#} \mathrm{SX}=$ Simmentaler crosses; BX = Bonsmara crosses; NG = Nguni;

* \% of carcass weight

L*; 0 = black, 100 = white; redness $\left(\mathrm{a}^{*} ;++=\right.$ red, - = green $)$ and yellowness $\left(\mathrm{b}^{*} ;+\right.$ = yellow, - = blue $)$

The only significant breed difference (across age groups) detected for any sensory trait was for sustained juiciness between meat from BX (mean $=6.71$ ) and SX steers (mean $=6.14)$. No differences were detected between any of the breed $x$ slaughter age combinations for tenderness (Table 2). However, when the data were pooled for slaughter age, the panel rated meat from steers from the 30-month old group tougher ( $\mathrm{P}$ $<0.05)$ than meat from the 18-month old group. Although no interaction $(\mathrm{P}>0.05)$ occurred between breed and slaughter age regarding WBS-values (Table 2), SX steers presented a higher $(\mathrm{P}<0.05)$ value $(3.52$ $\pm 0.16 \mathrm{~kg} / 12.7 \mathrm{~mm}$ diameter $)$ than either BX $(2.63 \pm 0.85 \mathrm{~kg} / 12.7 \mathrm{~mm}$ diameter $)$ or NG steers $(2.87 \pm 0.15$ $\mathrm{kg} / 12.7 \mathrm{~mm}$ diameter). Furthermore, WBS-values were higher $(\mathrm{P}<0.05)$ at 30 months $(3.16 \pm 0.15 \mathrm{~kg} / 12.7$ $\mathrm{mm}$ diameter) than at 18 months of age (2.62 $\pm 0.13 \mathrm{~kg} / 12.7 \mathrm{~mm}$ diameter $)$. 
Table 2 Rank means (mean) for the sensory quality characteristics and means ( \pm s.e.) for shear force values of the Longissimus muscle as influenced by different beef breed and slaughter age (months) combinations

\begin{tabular}{|c|c|c|c|c|c|c|}
\hline $\begin{array}{r}\text { Breed }^{\#} \\
\text { Age }\end{array}$ & $\begin{array}{l}\text { SX } \\
18 \\
\end{array}$ & $\begin{array}{c}\mathrm{BX} \\
18 \\
\end{array}$ & $\begin{array}{c}\text { NG } \\
18 \\
\end{array}$ & $\begin{array}{l}\text { SX } \\
30 \\
\end{array}$ & $\begin{array}{c}\mathrm{BX} \\
30 \\
\end{array}$ & $\begin{array}{c}\text { NG } \\
30 \\
\end{array}$ \\
\hline Aroma $^{a}$ & $\begin{array}{c}1.820 \\
(5.960)\end{array}$ & $\begin{array}{c}1.814 \\
(5.857)\end{array}$ & $\begin{array}{c}2.029 \\
(6.057)\end{array}$ & $\begin{array}{c}2.100 \\
(6.133)\end{array}$ & $\begin{array}{c}1.660 \\
(5.920)\end{array}$ & $\begin{array}{c}1.880 \\
(6.160)\end{array}$ \\
\hline $\begin{array}{l}\text { Initial } \\
\text { juiciness }\end{array}$ & $\begin{array}{c}2.120 \\
(6.600)\end{array}$ & $\begin{array}{c}1.829 \\
(6.486)\end{array}$ & $\begin{array}{c}1.800 \\
(6.343)\end{array}$ & $\begin{array}{c}2.000 \\
(6.467)\end{array}$ & $\begin{array}{c}1.920 \\
(6.560)\end{array}$ & $\begin{array}{c}1.680 \\
(6.400)\end{array}$ \\
\hline $\begin{array}{l}\text { Sustained } \\
\text { juiciness }{ }^{c}\end{array}$ & $\begin{array}{c}1.880 \\
(5.640)\end{array}$ & $\begin{array}{c}1.971 \\
(5.742)\end{array}$ & $\begin{array}{c}1.829 \\
(5.543)\end{array}$ & $\begin{array}{c}2.033 \\
(5.600)\end{array}$ & $\begin{array}{c}2.060 \\
(5.920)\end{array}$ & $\begin{array}{c}1.520 \\
(5.360)\end{array}$ \\
\hline Tenderness $^{\mathrm{d}}$ & $\begin{array}{c}2.100 \\
(6.400)\end{array}$ & $\begin{array}{c}2.043 \\
(6.629)\end{array}$ & $\begin{array}{c}1.600 \\
(6.114)\end{array}$ & $\begin{array}{c}1.933 \\
(5.200)\end{array}$ & $\begin{array}{c}2.000 \\
(5.720)\end{array}$ & $\begin{array}{c}1.640 \\
(5.480)\end{array}$ \\
\hline Residue $^{\mathrm{e}}$ & $\begin{array}{c}2.120 \\
(6.680)\end{array}$ & $\begin{array}{c}2.000 \\
(6.743)\end{array}$ & $\begin{array}{c}1.629 \\
(6.486)\end{array}$ & $\begin{array}{c}1.833 \\
(5.733)\end{array}$ & $\begin{array}{c}2.060 \\
(6.600)\end{array}$ & $\begin{array}{c}1.640 \\
(6.160)\end{array}$ \\
\hline Flavour $^{\mathrm{f}}$ & $\begin{array}{c}2.020 \\
(6.240)\end{array}$ & $\begin{array}{c}1.757 \\
(5.743)\end{array}$ & $\begin{array}{c}1.943 \\
(6.057)\end{array}$ & $\begin{array}{c}1.900 \\
(5.867)\end{array}$ & $\begin{array}{c}1.980 \\
(6.280)\end{array}$ & $\begin{array}{c}1.680 \\
(6.040)\end{array}$ \\
\hline Shear force ${ }^{h}$ & $3.27 \pm 0.12$ & $2.37 \pm 0.20$ & $2.66 \pm 0.20$ & $3.71 \pm 0.23$ & $2.98 \pm 0.25$ & $3.07 \pm 0.23$ \\
\hline $\begin{array}{l}{ }^{\#} \text { SX = Simme } \\
\text { a } 1=\text { Extremely } \\
\text { c } 1=\text { Extremely } \\
\text { e } 1=\text { Abundant; } \\
\text { g } 1=\text { Abundant; }\end{array}$ & $\begin{array}{l}\text { ler crosses; B } \\
\text { and; } 8=\text { Extren } \\
\text { y; 8=Extreme } \\
=\text { None } \\
=\text { None }\end{array}$ & $\begin{array}{l}\text { Bonsmara cr } \\
\text { intense } \\
\text { dicy }\end{array}$ & 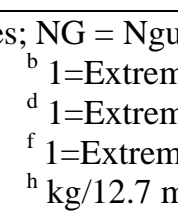 & $\begin{array}{l}\text { ry; 8=Extren } \\
\text { ough; 8=Extr } \\
\text { nflavoured; } 8 \\
\text { ameter }\end{array}$ & $\begin{array}{l}\text { juicy } \\
\text { y tender } \\
\text { tremely flavo }\end{array}$ & \\
\hline
\end{tabular}

\section{Discussion}

Differences in LW and CCW among the breed types used in this study are in general agreement with results from previous studies that the larger frame-sized breed types attain heavier final weights and have heavier carcasses than the smaller frame-sized breed type. Heavier $(\mathrm{P}<0.05) \mathrm{LW}$ and carcass weights have been reported for large-framed steers than for small-framed steers at a constant age (Wheeler et al., 1996; Camfield et al., 1999; Short et al., 1999) as well as at a constant carcass fat content (Tatum et al., 1986b; Dolezal et al., 1993; Wheeler et al., 1996). Bidner et al. (1986) reported similar LW for pasture raised Angus x Hereford and Brahman cross steers at 31 months of age, as was observed for SX and BX steers in the present study. Schaake et al. (1993), however, reported appreciably higher warm carcass weights (281.9 $\mathrm{kg}$ and $291.4 \mathrm{~kg}$ ) for steers slaughtered from pastures at approximately 18 months of age.

Higher DP have been reported for intensively fed cattle (Schroeder et al., 1980; Bidner et al., 1986; Swanepoel et al., 1990; Bennett et al., 1995; Keane \& Allen, 1998; Strydom et al., 2001) than for forage fed cattle. This was mainly ascribed to less body fill as well as a higher carcass fat content in intensively fed animals, and probably explains the low DP observed in this study. The DP obtained in the current study are in general agreement with the results of Bidner et al. (1986), but contrary to the findings of Prior et al. (1977), Dolezal et al. (1993) and Camfield et al. (1999) who reported higher (P < 0.05) DP for large-framed steers than for small-framed steers, and Swanepoel et al. (1990) who noted that NG bulls had higher DP than Afrikaner and Pedi bulls, all under intensive feeding conditions. Although increased DP with increased age was observed in previous studies (Short et al., 1999), in the present study DP of steers slaughtered in the 18 month and 30 month old groups were similar.

In concurrence with the results from this study, Swanepoel et al. (1990) reported that carcass compactness increased with increasing animal age. These authors also reported higher carcass compactness for NG bulls than for Afrikaner and Pedi bulls, which is contrary to the observations made in the present study. Strydom et al. (2001) reported higher carcass compactness for Bonsmara (0.91 to 0.94) and Nguni (0.74) bulls than was observed for 30-month old steers in the present study. The observed differences in 
carcass compactness between the respective breed types are in agreement with the results of Tatum et al. (1986b) who indicated that there is a strong correlation $(\mathrm{r}=0.96)$ between hip height and frame size, but a low correlation (ranging from 0.09 to 0.48 ) between other body measurements (body length, width and girth) and frame size. They indicated that although all body measurements increased with an increase in frame size, body length, width and girth were not always proportional to corresponding differences in heights. Largeframed animals thus tend to be disproportionately tall with relative short and narrow bodies compared to small-framed cattle that were short, but relatively highly developed in length, width and girth.

In studies with intensive feeding regimens differences between breeds regarding the various fat parameters have been reported. Breed differences in BFT were reported by Koch et al. (1979), Loveday \& Dikeman (1980), Tatum et al. (1990) and Wheeler et al. (1996) at constant weight as well as age end-points, while Camfield et al. (1999) observed higher $(\mathrm{P}<0.05)$ BFT and KPH fat percentages for steers of smaller framed breed types compared to steers of larger framed breed types. Swanepoel et al. (1990) did not observe any significant breed differences in BFT between Afrikaner, NG and Pedi bulls, but the percentage kidney and channel fat was higher for Pedi bulls than for Afrikaner $(\mathrm{P}<0.05)$ and NG bulls $(\mathrm{P}<0.01)$. On the contrary, Tatum et al. (1990) did not observe breed differences in kidney, pelvic and heart (KPH) fat percentage between Piedmontese, Gelbvieh and Red Angus steers. Swanepoel et al. (1990) did not observe significant differences in OF percentage between the different breeds. At equal BFT, Simmentaler cattle had significantly ( $\mathrm{P}$ 0.05) more KPH fat than Angus cattle (Crouse et al., 1985a). However, Block et al. (2001) found no significant differences in body cavity fat percentage at equal BFT between Angus, Charolais and Hereford steers.

On lower energy diets the differences between breeds become less pronounced or in most cases even trivial. Sprinkle et al. (1998) reported no significant differences in BFT, KPH fat and OF among British, Tuli, Boran and Brahman steers with limited access to a maize-based diet, but differences between breeds were significant $(\mathrm{P}<0.05)$ when steers from these breeds had ad libitum access to the diet. Increased BFT as well as KF percentage with increasing grain feeding were also observed by Bowling et al. (1977), Young \& Kauffman (1978), Danner et al. (1980) Schroeder et al. (1980), Newsome et al. (1985), May et al. (1992) and Schaake et al. (1993), while Prior et al. (1997) reported that BFT and KPH fat of small-framed breeds increased significantly $(\mathrm{P}<0.05)$ with increasing energy level in the diet, but not that of large-framed breeds.

Although Bidner et al. (1986) observed higher BFT for pasture raised Hereford-Angus cross steers than was observed in the present study, the results observed for the respective fat parameters of the present study are in general agreement with previous studies. In concurrence with the conclusion of Short et al. (1999) the effect of the sire breed on fat parameters became more pronounced with increasing age.

Even though NG steers had a higher percentage internal fat than the SX and BX steers, their dressing percentage was similar to that of the SX and BX steers. The reason for this is possibly due to the relatively lighter hide (Swanepoel et al., 1990) of NG as well as differences in fat partitioning. Swanepoel et al. (1990) reported that at a LW of $390 \mathrm{~kg}$, hides from NG bulls weighed approximately $1.5 \mathrm{~kg}$ less than that of Afrikaner bulls. The NG steers also accumulated more carcass fat than the other breeds as the BFT for the 30 -month old steers were double that of the 18-month old steers, while BFT of BX increased with $84 \%$ and that of SX steers with $16 \%$.

Although breed did not have a major effect on the meat quality attributes (drip loss, cooking loss, colour, $\mathrm{pH}_{24}$, panel tenderness and WBS-values), slaughter age did. The meat was more tender at 18 months of age than at 30 months of age $(\mathrm{P}<0.05)$ while the $\mathrm{pH}_{24}$ was also lower at 18 months of age $(\mathrm{P}<0.05)$. The $\mathrm{pH}_{24}$ was not high enough to result in dark cutting meat. It appears that meat quality was probably influenced by carcass fatness and consequently cooling rate rather than by ante mortem muscle glycogen concentration.

Although Keane \& Allen (1998) observed no significant differences in drip loss due to feeding system, they noted differences $(\mathrm{P}<0.05)$ among light and heavy slaughter groups. Crouse et al. (1984) reported cooking losses for grain as well as pasture raised steers that are similar to that observed in the present study. Camfield et al. (1997) reported that although cooking loss was similar for meat from steers fed for 0 and 90 days it was higher $(\mathrm{P}<0.05)$ than for meat from steers fed for 30 and 60 days. Comparing Afrikaner, Nguni and Pedi bulls, Swanepoel et al. (1990) observed no breed differences in the cooking loss of the longissimus muscle, but Whipple et al. (1990) observed that cooking loss increased as the percentage of Bos indicus increased.

Young \& Kauffman (1978) and Newsome et al. (1985) reported very little dietary effects (forage vs. grain fed) on the subjectively evaluated lean colour of carcasses. However, Newsome et al. (1985) found that 
at 3 days post mortem steaks from grain fed steers had a higher $(\mathrm{P}<0.05)$ reflectance of light than steaks from forage fed steers. Similarly, Schroeder et al. (1980), Bidner et al. (1986), Schaake et al. (1993) and Bennett et al. (1995) reported that forage-fed steers had darker meat (subjectively measured) than grain-fed steers. Similar results were reported by Keane \& Allen (1998) for objectively measured Hunter lab L* colour values among longissimus muscle steaks from intensively and extensively reared steers. Keane \& Allen (1998) also reported higher $\mathrm{a} *(\mathrm{P}<0.05)$ and $\mathrm{b}^{*}$ colour values $(\mathrm{P}<0.001)$ for longissimus muscle steaks from intensively raised steers than for longissimus muscle steaks from extensively raised steers.

Devine et al. (1993) observed that muscle from young lambs (7 months of age) has lower $(\mathrm{P}<0.05)$ ultimate $\mathrm{pH}$ values than that from older lambs (14 months of age), which is similar to what was observed in the present study. Young et al. (2004) concluded that the most desirable range for muscle $\mathrm{pH}$ that results in the best properties for table cuts is 5.4 to 5.6. Results of Devine et al. (1993) support this conclusion as they reported that WBS-values increased as the ultimate $\mathrm{pH}$ increased from 5.5 to 5.9 and also that WBS-values of meat from young and older animals with similar $\mathrm{pH}$-values were similar. Devine et al. (1993) concluded that age-related tenderness effects were minor compared to $\mathrm{pH}$ effects. Rees et al. (2003) indicated that the rate of $\mathrm{pH}$ and temperature decline can influence tenderness due to two main factors; (1) Cold shortening occurs when the temperature falls below $10{ }^{\circ} \mathrm{C}$ while muscle $\mathrm{pH}$ is still above 6.0 and (2) if the temperature declines slowly and $\mathrm{pH}$ rapidly, protein denaturation may occur. The latter event leads to a reduction of the proteolytic processes necessary for tenderization of meat. The fat thickness of the carcass is believed to be associated with a part of the difference in tenderness of beef due to its effect on temperature decline and thus also $\mathrm{pH}$ decline. Bowling et al. (1977) reported that sarcomere length and panel tenderness ratings increased while shear force values decreased when fat thickness increased from $1.27 \mathrm{~mm}$ to $8.9 \mathrm{~mm}$, while May et al. (1992) found no improvement in tenderness after steers reached a BFT of $7.6 \mathrm{~mm}$. Although the role of $\mathrm{pH}$ cannot be ignored completely, it is doubtful that $\mathrm{pH}$ had a major influence on the tenderness of the meat in the present study. Most probably the natural aging processes and their effect on the content and properties of collagen as explained by Hill (1966), Bailey (1985) and McCormick (1994) played a more prominent role. Although the $\mathrm{pH}_{24}$-values of the steers slaughtered at 30 months fell marginally outside the range defined by Young et al. (2004), the WBS-values and sensory panel tenderness ratings were still within acceptable tenderness norms. Any WBS-values higher than $5.0 \mathrm{~kg}$ (Whipple et al., 1990) were deemed unacceptable, while panel tenderness scores between 6.82 and 7.44 (scale of 1 to 9) were deemed moderately tender by Koch et al. (1979). Although a trained sensory panel identified differences in tenderness between steers slaughtered at 18 and 30 months of age, these differences were not large and were within a moderately tender class. It is thus unlikely that consumers will discriminate against beef from 30-month old steers compared to beef from 18-month old steers.

The present results are contrary to the results of Casey et al. (1990) who did not observe any breed differences in WBS-values or sensory panel tenderness of the longissimus muscle of Afrikaner, NG and Pedi bulls. Crouse et al. (1985a) did not find significant differences in WBS-values or sensory panel tenderness of longissimus and semimembranosus steaks from Angus and Simmentaler cattle. Although Strydom et al. (2001) did not find significant differences in WBS-values between different strains of Bonsmara or NG bulls, sensory panel tenderness differed $(\mathrm{P}<0.05)$ among the different strains. In contrast, Strydom et al. (2000) reported in earlier research that although Santa Gertrudis bulls had higher $(\mathrm{P}<0.05)$ WBS-values than Bonsmara, Pinzgauer, Brown Swiss, Afrikaner and NG bulls, sensory panel tenderness did not differ significantly between the various breeds. Similar results were reported by Koch et al. (1979), Knapp et al. (1989) and Wheeler et al. (1996). On the other hand, Whipple et al. (1990) reported that WBS-values for longissimus muscle steaks increased $(\mathrm{P}<0.05)$ and that sensory panel tenderness decreased $(\mathrm{P}<0.01)$ as the percentage $B$. indicus increased, but not in steaks from the semimembranosus muscle.

Mixed results were reported for dietary effects (especially the effect of energy or grain content) on WBS-values and sensory panel traits of beef. Prior et al. (1977) reported little influence of dietary energy and protein level on WBS-values and sensory traits of meat from small-framed Angus x Hereford and largeframed Charolais and Chianina steers and concluded that all carcasses of both types of cattle had acceptable palatability. Significantly higher WBS-values and lower tenderness ratings were observed for pasturefinished than for grain-finished steers (Bowling et al., 1977; Schroeder et al., 1980). Schaake et al. (1993) as well as Bennett et al. (1995) reported lower WBS-values for longissimus muscle steaks of feedlot steers than for steaks of pasture raised steers, but steaks of pasture fed steers were rated more tender than steaks of feedlot fed steers by a trained sensory panel. Short et al. (1999) observed that WBS-values decreased 
(became tender) and that sensory panel tenderness increased $(\mathrm{P}<0.01)$ with increasing time on a feedlot diet. Although the results of Camfield et al. (1997) and Keane \& Allen (1998) also indicate a tendency for WBSvalues to decrease and sensory panel tenderness ratings to increase with increasing time in a feedlot, it was not significant. Crouse et al. (1984) and Bidner et al. (1986) reported no effect of diet on WBS-values or sensory panel tenderness of the longissimus muscle. Although Crouse et al. (1985b) also observed no significant influence of diet on the WBS-values of meat, the sensory panel rated meat produced on a low energy diet to be more tender $(\mathrm{P}<0.01)$ than meat produced on a high energy diet.

Koch et al. (1979), Knapp et al. (1989), Whipple et al. (1990), Wheeler et al. (1996) and Strydom et al. (2000) reported similar results for juiciness and flavour. Breed differences $(\mathrm{P}<0.05)$ for connective tissue amount and flavour intensity scores, but not for juiciness scores were observed by Tatum et al. (1990). Whipple et al. (1990) observed that the connective tissue amount score (similar to residue in Table 2) decreased (became more) with increasing $B$. indicus, but similar to the results of the present study, Knapp et al. (1989) and Strydom et al. (2000) found no significant difference among breeds in the score for connective tissue amount with increasing B. indicus. Casey et al. (1990) found no significant differences between breeds for juiciness, flavour and residue, but residue score increased with increasing slaughter weight. Keane \& Allen (1998) observed higher juiciness scores at higher slaughter weights. Juiciness scores also increased with increasing levels of marbling, but flavour intensity was not affected significantly (Wheeler et al., 1996).

Crouse et al. (1985a) observed no breed effects for juiciness, flavour and connective tissue amount, but the meat from the low energy diet had a lower connective tissue content $(\mathrm{P}<0.01)$ and flavour intensity score $(\mathrm{P}<0.05)$ than beef from the high energy diet. Similar results were reported by Bowling et al. (1977), Schroeder et al. (1980), Bidner et al. (1986) and Bennet et al. (1995). Camfield et al. (1997) and Short et al. (1999) reported that connective tissue content and flavour intensity scores increased with increased time on feed, but juiciness was not affected by time in a feedlot. Similarly, May et al. (1992) observed that connective tissue content scores increased with increasing time in a feedlot, but juiciness and flavour intensity were not affected. In contrast, no significant differences in sensory panel scores were observed for beef from grain and pasture fed heifers (Crouse et al., 1984) and varying levels of energy in the diet (Prior et al., 1977). Inconsistent results for juiciness and connective tissue content for beef produced from pastures and various times in a feedlot were also reported by Schaake et al. (1993), while Young and Kauffman (1978) observed lower $(\mathrm{P}<0.05)$ juiciness and higher $(\mathrm{P}<0.05)$ flavour intensity scores for forage fed compared to grain fed steers.

It seems from the results of the present as well as previous studies that breed as well as diet only has minor effects on the sensory traits of beef. It also seems that animal age at slaughter has a more distinct effect on the sensory traits.

\section{Conclusions}

While breed and slaughter age influenced LW and carcass traits significantly, age at slaughter, which is the product of age as well as the environment, had a much more pronounced influence on meat quality traits than breed, possibly the result of the combined effects of fatness, $\mathrm{pH}$ and collagen characteristics. Steers from small-framed breed types (born from October to December) grazing natural sweet veld pastures will to some extent be finished off sufficiently for slaughtering at the end of the wet summer season at an age of 18 months and will be finished off to a greater extent at 30 months of age. On the other hand, steers from medium-framed breed types will only be successfully finished off for slaughtering at 30 months of age. Carcasses of steers from small-framed breed types may, however, be too small (mean $=134 \mathrm{~kg}$ ) at 18 months of age to be readily accepted by the market. It may thus be beneficial to supplement or even feedlot steers to be slaughtered before the age of 30 months of age. This aspect, however, requires further research to determine the nutritional and cost implications that may result from this practice. As WBS-values and sensory panel tenderness scores were within moderately tender norms, it is doubtful that consumers will discriminate against beef from pasture-raised steers slaughtered at 30 months of age. Rigid slaughtering ages at the end of the wet season were used in this study. Undoubtedly the quality of the grazing was already in a decreasing phase. Thus, it is possible that steers may have been in a better condition prior to 18 and 30 months of age. Visual appraisal from 15 and 26 months of age onwards may identify animals suitable for slaughtering at a slightly younger age. 


\section{References}

Acocks, J.P.H., 1988. Veld types of South Africa. Memoirs of the Botanical Survey of South Africa 57.

American Meat Science Association, 1978. Guidelines for cookery and sensory evaluation of meat. Chicago, IL: American Meat Science Association, National Livestock and Meat Board.

Bailey, A.J., 1985. The role of collagen in the development of muscle and its relationship to eating quality. J. Anim. Sci. 60, 1580-1587.

Bennett, L.L., Hammond, A.C., Williams, M.J., Kunkle, W.E., Johnson, D.D., Preston, R.L. \& Miller, M.F., 1995. Performance, carcass yield and carcass quality characteristics of steers finished on Rhizoma peanut (Arachis glabrata) - Tropical grass pasture or concentrate. J. Anim. Sci. 73, 1881-1887.

Bidner, T.D., Schupp, A.R., Mohamad, A.B., Rumore, N.C., Montgomery, R.E., Bagley, C.P. \& Mcmillin, K.W., 1986. Acceptability of beef from Angus-Hereford or Angus-Hereford-Brahman steers finished on all-forage or a high-energy diet. J. Anim. Sci. 62, 381-387.

Block, H.C., McKinnon, J.J., Mustafa, A.F. \& Christensen, D.A., 2001. Manipulation of cattle growth to target carcass quality. J. Anim. Sci. 79, 133-140.

Bowling, R.A., Smith, G.C., Carpenter, Z.L., Dutson, T.R. \& Oliver, W.M., 1977. Comparison of foragefinished and grain-finished beef carcasses. J. Anim. Sci. 45, 209-215.

Brand, A.A., Cloete, S.W.P. \& Coetzee, J., 1989. Urea ammoniation of wheat, oat and barley straw and oat hay. 1. A laboratory investigation into the effect of urea and moisture level and treatment period on chemical composition and in vitro digestibility. S. Afr. J. Anim. Sci. 19, 4-10.

Camfield, P.K., Brown Jr, A.H., Lewis, P.K., Rakes, L.Y. \& Johnson, Z.B., 1997. Effects of frame size and time-on-feed on carcass characteristics, sensory attributes and fatty acid profiles of steers. J. Anim. Sci. 75, 1837-1844.

Camfield, P.K., Brown Jr, A.H., Johnson, Z.B., Brown, C.J., Lewis, P.K. \& Rakes, L.Y., 1999. Effects of growth type on carcass traits of pasture- or feedlot-developed steers. J. Anim. Sci. 77, 2437-2443.

Casey, N.H., Swanepoel, J., de Bruyn, J.F. \& Naudé, R.T., 1990. Meat studies of indigenous Southern African cattle. II. Textural evaluation of ribcut samples from carcasses of Afrikaner, Nguni and Pedi bulls fed intensively. S. Afr. J. Anim. Sci. 20, 188-192.

Cianzio, D.S., Topel, D.G., Whitehurst, G.B., Beitz, D.C. \& Self, H.L., 1982. Adipose tissue growth in cattle representing two frame sizes: Distribution among depots. J. Anim. Sci. 55, 305-312.

Cloete, S.W.P. \& Kritzinger, N.M., 1985. A laboratory assessment of various treatment conditions affecting the ammoniation of wheat straw by urea. 2. The effect of physical form, moisture level, and prolonged treatment period. S. Afr. J. Anim. Sci. 15, 137-141.

Crouse, J.D., Cross, H.R. \& Seideman, S.C., 1984. Effects of a grass or grain diet on the quality of three beef muscles. J. Anim. Sci. 58, 619-625.

Crouse, J.D., Ferrel, C.L. \& Cundiff, L.V., 1985a. Effects of sex condition, genotype and diet on bovine growth and carcass characteristics. J. Anim. Sci. 60, 1219-1227.

Crouse, J.D., Cross, H.R. \& Seideman, S.C., 1985b. Effects of sex condition, genotype, diet and carcas electrical stimulation on the collagen content and palatibility of two bovine muscles. J. Anim. Sci. 60, 1228-1234.

Danner, M.L., Fox, D.G. \& Black, J.R., 1980. Effect of feeding system on performance and carcass characteristics of yearling steers, steer calves and heifer calves. J. Anim. Sci. 50, 394-404.

Dekker, B., Kirkman K.P. \& Du Plessis, S.I., 2001. Use of the dry-weight-rank method of botanical analysis in semi-arid savanna communities. Afr. J. Range For. Sci. 19, 63-68.

Devine, C.E., Graafhuis, A.E., Muir, P.D. \& Chrystall, B.B., 1993. The effect of growth rate and ultimate pH on meat quality of lambs. Meat Sci. 35, 63-77.

Dolezal, H.G., Tatum, J.D. \& Williams Jr, F.L., 1993. Effects of feeder cattle frame size, muscle thickness and age class on days fed, weight and carcass composition. J. Anim. Sci. 71, 2975-2985.

Du Plessis, I. \& Hoffman, L.C., 2004. Effect of chronological age of beef steers of different maturity types on their growth and carcass characteristics when finished on natural pastures in the arid sub-tropics of South Africa. S. Afr. J. Anim. Sci. 34, 1-12.

Erasmus, J.A. \& Barnard, H.H., 1985. Supplementary winter feeding and reproduction of beef heifers on Dohne sourveld. S. Afr. J. Anim. Sci. 15, 162-164.

Gertenbach, W.D. \& Van H. Henning, P.W., 1995a. Energy supplementation of yearling steers at different stocking rates on Nile grass pasture. S. Afr. J. Anim. Sci. 25, 105-108. 
Gertenbach, W.D. \& Van H. Henning, P.W., 1995b. Performance of beef steers on Smuts finger grass and Nile grass pasture in Northern Natal. 2. Feedlot performance following summer grazing. S. Afr. J. Anim. Sci. 25, 101-104.

Fortin, A., Veira, D.M., Froehlich, D.A., Butler, G. \& Proulx, J.G., 1985. Carcass characteristics and sensory properties of Hereford $\mathrm{x}$ Shorthorn bulls and steers fed different levels of grass silage and high moisture barley. J. Anim. Sci. 60, 1403-1411.

Hill, F., 1966. The solubility of intramuscular collagen in meat animals of various ages. J. Food Sci. 31, 161-166.

Honikel, K.O., 1998. Reference methods for the assessment of physical characteristics of meat. Meat Sci. 49, 447-457.

Keanne, M.G. \& Allen, P., 1998. Effects of production system intensity on performance, carcass composition and meat quality of beef cattle. Livest. Prod. Sci. 56, 203-214.

Knapp, R.H., Terry, C.A., Savell, J.W., Cross, H.R., Mies, W.L. \& Edwards, J.W., 1989. Characterization of cattle types to meet specific beef targets. J. Anim. Sci. 67, 2294-2308.

Koch, R.M., Dikeman, M.E., Allen, D.M., May, M., Crouse, J.D. \& Campion, D.R., 1976. Characterization of biological types of cattle. III. Carcass composition, quality and palatability. J. Anim. Sci. 43, 48-62.

Koch, R.M., Dikeman, M.E., Lipsey, R.J., Allen, D.M. \& Crouse, J.D., 1979. Characterization of biological types of cattle - Cycle II: III. Carcass composition, quality and palatability. J. Anim. Sci. 49, 448-460.

Lademann, E.E., 1992. Faktore wat herkonsepsie van vleisraskoeie in die Noord-Transvaalse Soetbosveld beïnvloed. M.Sc. thesis, University of Pretoria. pp 249.

Le Roux, C.J.G., Swart, J.S., Oosthuysen, E., Trethewey, C., Pittaway, C. \& Daines, T., 1999. Prediction of cattle performance on Coastcross 2 at different fertilizer and stocking rates. S. Afr. J. Anim. Sci. 29, 64-68.

Loveday, H.D. \& Dikeman, M.E., 1980. Diet energy and steer type effects on adipose composition, lopogenesis and carcass composition. J. Anim. Sci. 51, 78-88.

May, S.G., Dolezal, H.G., Gill, D.R., Ray, F.K. \& Buchanan, D.S., 1992. Effects of days fed, carcass grade traits and subcutaneous fat removal on post mortem muscle characteristics and beef palatability. J. Anim. Sci. 70, 444-453.

McCormick, R.J., 1994. The flexibility of the collagen compartment of muscle. Meat Sci. 30, 79-91.

Meaker, H.J. \& Barnard, J.C., 1988. Beef steers implanted with short, medium and long-acting anabolic compounds grazing natural pastures and finished in feedlot. S. Afr. J. Anim. Sci. 18, 68-71.

Meaker, M.J., 1993. The effect of genotype on cow efficiency in extensive beef production in the northern Transvaal sweet Bushveld. M.Sc. (Agric) thesis, University of Pretoria. pp. 179.

Newsome, R.L., Moody, W.G., Lanlois, B.E., Gay, N., McMillan, M. \& Fox, J.D., 1985. Effects of cattlefinishing systems on carcass traits and aging methods on loin shrinkage and steak color. J. Anim. Sci. 60, 1208-1218.

Prior, R.L., Kohlmeier, R.H., Cundiff, L.V., Dikeman, M.E. \& Crouse, J.D., 1977. Influence of dietary energy and protein on growth and carcass composition in different biological types of cattle. J. Anim. Sci. 45, 132-146.

Rees, M.P., Trout, G.R. \& Warner R.D., 2003. The influence of the rate of pH decline on the rate of ageing for pork. I: Interaction with method of suspension. Meat Sci. 65, 791-804.

SAS, 1990. SAS/STAT User's guide, Version 6. (4 ${ }^{\text {th }}$ Ed.). Cary, NC: SAS Institute Inc.

Schaake, S.L., Skelley, G.C., Halpin, E., Grimes. L.W., Brown, R.B., Cross, D.L. \& Thompson, C.E., 1993. Carcass and meat sensory traits of steers finished on fescue and clover, summer forage, or for different periods in drylot. J. Anim. Sci. 71, 3199-3205.

Schroeder, J.W., Cramer, D.A., Bowling, R.A. \& Cook, C.W., 1980. Palatability, shelf life and chemical differences between forage- and grain finished beef. J. Anim. Sci. 50, 852-859.

Short, R.E., Grings, E.E., MacNeil, M.D., Heitschmidt, R.K., Williams, C.B. \& Bennett, G.L., 1999. Effects of sire growth potential, growing-finishing strategy and time on feed on performance, composition and efficiency of steers. J. Anim. Sci. 77, 2406-2417.

Snyman, L.D. \& Joubert, H.W., 2002. The chemical composition and in vitro dry matter digestibility of untreated and ammoniated crop residues. S. Afr. J. Anim. Sci. 32, 83-87. 
Sprinkle, J.E., Ferrel, C.L., Holloway, J.W., Warrington, B.G., Greene, L.W., Wu, G. \& Stuth, J.W., 1998. Adipose tissue partitioning of limit-fed beef cattle and beef cattle with ad libitum access to feed differing in adaptation to heat. J. Anim. Sci. 76, 665-673.

Stevenson, J.M., Seman, D.L., Weatherall, I.L. \& Littlejohn, R.P., 1989. Evaluation of venison color by an objective method using calieb values. J. Food Sci. 54, 1661-1662.

Strydom, P.E., Naudé, R.T., Smith, M.F., Scholtz, M.M. \& Van Wyk, J.B., 2000. Characterisation of indigenous African cattle breeds in relation to meat quality traits. Meat Sci. 35, 79-88.

Strydom, P.E., Naudé, R.T., Smith, M.F., Kotze, A., Scholtz, M.M. \& Van Wyk, J.B., 2001. Relationships between production and product traits in subpopulations of Bonsmara and Nguni cattle. S. Afr. J. Anim. Sci. 31, 181-194.

Swanepoel, J., Casey, N.H., De Bruyn, F.J. \& Naude, R.T., 1990. Meat studies of indigenous southern African cattle. I. Growth performance and carcass characteristics of Afrikaner, Nguni and Pedi bulls fed intensively. S. Afr. J. Anim. Sci. 20, 180-187.

Tatum, J.D., Dolezal, H.G., Williams Jr, F.L., Bowling, R.A. \& Taylor, R.E., 1986a. Effects of feeder-cattle frame size and muscle thickness on subsequent growth and carcass development. II. Absolute growth and associated changes in carcass composition. J. Anim. Sci. 62, 121-131.

Tatum, J.D., Dolezal, H.G., Williams Jr, F.L., Bowling, R.A. \& Taylor, R.E., 1986b. Effects of feeder-cattle frame size and muscle thickness on subsequent growth and carcass development. I. An objective analysis of frame size and muscle thickness. J. Anim. Sci. 62, 109-120.

Tatum, J.D., Gronewald, K.W., Seideman, S.C. \& Lamm, W.D., 1990. Composition and quality of beef from steers sired by Piedmontese, Gelbvieh and Red Angus bulls. J. Anim. Sci. 68, 1049-1060.

Taute, A., Van Niekerk, W.A., Rethman, N.F.G. \& Coertze, R.J., 2002. An evaluation of Nitrogen fertilised Panicum maximum cv. Gatton at different stages of maturity during autumn: 1 . Dry matter yield and certain qualitative parameters. S. Afr. J. Anim. Sci. 32, 208-216.

Van Zyl, J.G.E., 1990. Studies on the performance and efficiency of pure and crossbred cattle in an arid Bushveld environment. PhD. (Agric) thesis, University of Pretoria. pp 183.

Venter, H.A.W., 1977. Die invloed van voorspeense groei by sekere vleis-, dubbeldoel- en kruisrasse in die Noord-Transvaalse Soetbosveld. D.Sc. (Agric) thesis, University of Pretoria. pp. 331.

Viljoen, D.L., Muller, M., De Swart, J.B., Sadie, A. \& Vosloo, M.C., 2001. Computerized electronic temperature control system for thermal efficiency during baking in food research. Int. J. Cons. Stud. 25, 30-42.

Voisey, P.W., 1976. Engineering assessment and critique of instruments used for meat tenderness evaluation. J. Text. Stud. 7, 11-13.

Wheeler, T.L., Cundiff, L.V., Koch, R.M. \& Crouse, J.D., 1996. Characterization of biological types of cattle (Cycle IV): Carcass traits and longissimus palatability. J. Anim. Sci. 74, 1023-1035.

Whipple, G., Koohmaraie, M., Dikeman, M.E., Crouse, J.D., Hunt, M.C. \& Klemm, R.D., 1990. Evaluation of attributes that affect longissimus muscle tenderness in Bos taurus and Bos indicus cattle. J. Anim. Sci. 68, 2716-2728.

Young, A.W. \& Kauffman, R.G., 1978. Evaluation of beef from steers fed grain, corn silage or haylage-corn silage diets. J. Anim. Sci. 64, 41-47.

Young, O.A., West, J., Hart, A.L. \& Van Otterdijk, F.F.H., 2004. A method for early determination of meat ultimate pH. Meat Sci. 66, 493-498. 